\title{
QUATERNARY COMMUNITY LOSES GLENN GOODFRIEND
}

As scientists we each enjoy the genuine sense of discovery that comes from our daily work on earth systems and earth history. For most of us, our love of fieldwork is complemented by selfless hours of laboratory work and the camaraderie and inspiration that comes from collaborations with colleagues. The outgrowths of this process are the enduring publications that pass on our knowledge to others. On October 15, 2002, just before the national Geological Society of America annual meeting he rarely missed, Glenn A Goodfriend passed away prematurely at the age of 51 - he was one who had so much more to discover and pass on. Following serious health problems that apparently developed late last spring, he died at George Washington University Hospital of pneumonia and serious complications from rhinocerebral mucormycosis, a systemic fungal disease.

Glenn was a scientist with many talents across the fields of Quaternary stratigraphy, paleontology, zoology, biogeochemistry, geochronology, and paleoclimate. He also had interests in geoarcheology and was most widely known for his specialties in land snail ecology and amino acid racemization studies.

Much like Louis Agassiz, Glenn came to geology via zoology. As a native of New Rochelle, New York, Glenn earned his undergraduate degree in zoology from the University of Rhode Island in 1973. He later earned a Masters degree in Evolutionary Biology from University of Chicago in 1978 and a $\mathrm{PhD}$ in zoology from the University of Florida in 1983. From 1983 to 1988 he worked as a post-doctoral fellow and research scientist in the Isotope Department at the Weizmann Institute of Science in Israel, a top-ranking multidisciplinary research institution. His position there changed to that of senior scientist in the then, renamed, Department of Environmental Sciences \& Energy Research. After returning to the USA, he became a Senior Research Associate in the Geophysical Laboratory of the Carnegie Institution of Washington from 1990 to 1998 while also serving from 1993-1995 as an Adjunct faculty member at Johns Hopkins in the Environmental Earth Sciences and Policy Program. In 1998, Glenn then joined the Department of Earth and Environmental Sciences at George Washington University as a Research Professor until his death.

Glenn had published more than 40 scientific papers, not counting the ones he likely left unfinished on his computer due to health problems in recent months. As a broad thinker in his work, he had collaborations with scientists across a range of subdisciplines from taphonomy and paleontology to biogeochemistry. He is pictured below with Steven Jay Gould just a month or so before Gould died last year.

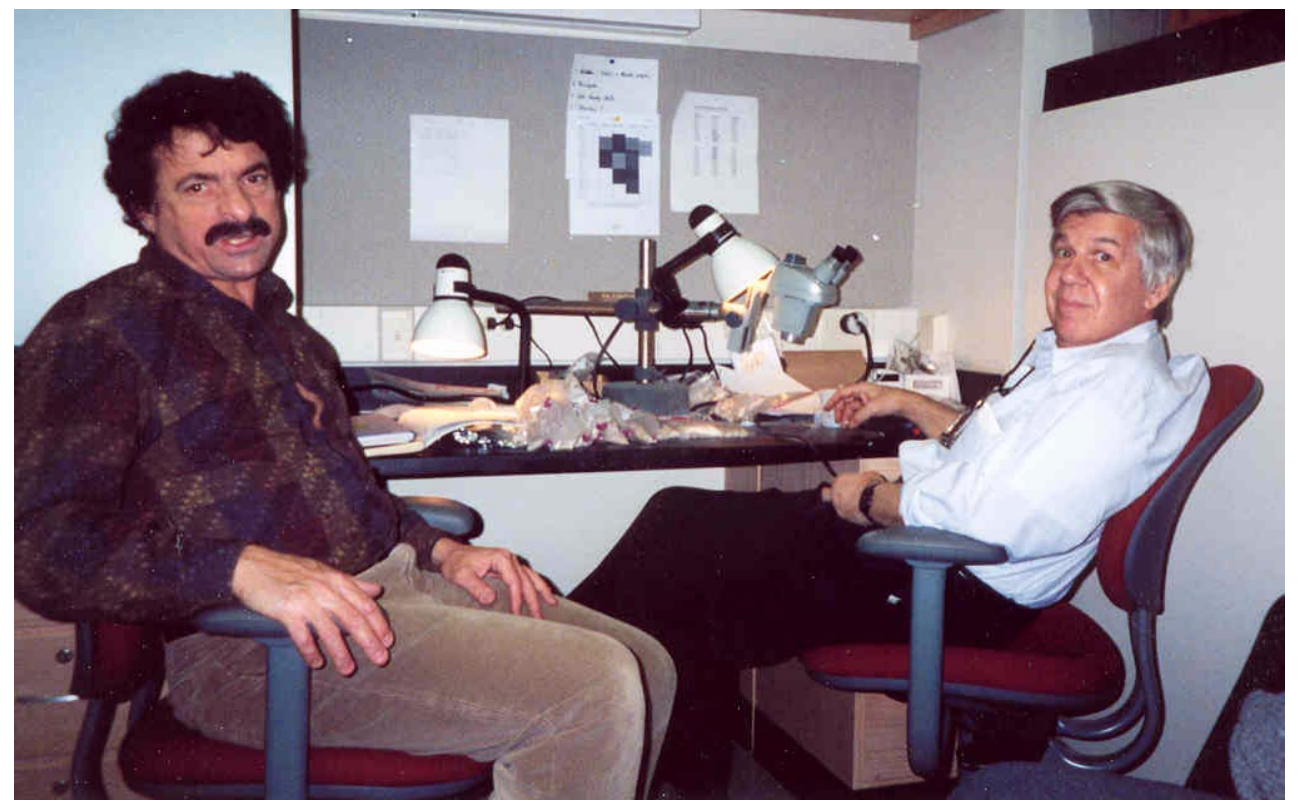

Glenn Goodfriend (at left) with Steven Jay Gould about one month before Gould died last year (photo courtesy of Bob Hazen, Carnegie Institute). 
Glenn most recently was the lead editor of a major volume on Perspectives in Amino Acid and Protein Geochemistry (Goodfriend GA, Collins MJ, Fogel ML, Macko SA, Wehmiller JF, editors. 2000. New York: Oxford University Press). At his untimely death, he had nearly $\$ 400,000$ in funded grants from the National Science Foundation including work on:

- "Geochronology and paleoecology of eggshells in central Africa in the context of human evolution"

- "Age mixing and taphonomy in Holocene shelf deposits, coastal Brazil"

- "Evolution and ecology of Cerion, a land snail from the Bahamas" (in collaboration with Steven Jay Gould)

- "Measurement of absorbed amino acids on mineral surfaces and the selectivity of absorption of amino-acid enantiomers".

According to John Wehmiller, University of Delaware, the current plans are for several of Glenn's colleagues, including John, to carry on Glenn's work and finish out the research he had started, something everyone is sure Glenn would have wanted. What I will remember most about Glenn was his gift of sharing and his attention to scientific detail. He allowed an eager senior honors student and I from the University of Massachusetts to pick his brain about lab procedures for a few days in his Carnegie lab. He then took a few more days out of his industrious schedule to visit me at the University of Massachusetts months later to follow up and help me troubleshoot a new lab instrument.

One of Glenn's favorite hobbies included the tasting of fine wines. Having been more interested in quantity rather than quality most of my life (a constant joke I had with him), I will never forget the night when Glenn, as a house guest, presented my husband and I with a bottle of wine so classy that you actually had to filter it before you drank it. On behalf of all of his many colleagues, let me summarize by saying that Glenn and his scientific creativity and contributions will be sorely missed. Like a fine wine, he is gone too soon.

Glenn is survived by his father and stepmother, Morton and Teresa Goodfriend of Huntley, Ill.

\section{Julie Brigham-Grette}

Professor \& Associate Department Head

Department of Geosciences

University of Massachusetts 